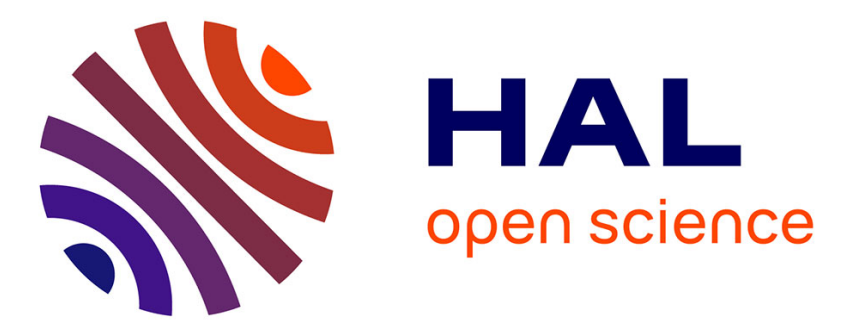

\title{
Production of green juice with an intensive thermo-mechanical fractionation process. Part II: Effect of processing conditions on the liquid fraction properties
}

S. Kerfai, A. Fernandez, S. Mathe, S. Alfenore, Patricia Arlabosse

\section{- To cite this version:}

S. Kerfai, A. Fernandez, S. Mathe, S. Alfenore, Patricia Arlabosse. Production of green juice with an intensive thermo-mechanical fractionation process. Part II: Effect of processing conditions on the liquid fraction properties. Chemical Engineering Journal, 2011, 167 (1), pp.132-139. 10.1016/j.cej.2010.12.011. hal-01643398

\section{HAL Id: hal-01643398 \\ https://hal.science/hal-01643398}

Submitted on 19 Dec 2017

HAL is a multi-disciplinary open access archive for the deposit and dissemination of scientific research documents, whether they are published or not. The documents may come from teaching and research institutions in France or abroad, or from public or private research centers.
L'archive ouverte pluridisciplinaire HAL, est destinée au dépôt et à la diffusion de documents scientifiques de niveau recherche, publiés ou non, émanant des établissements d'enseignement et de recherche français ou étrangers, des laboratoires publics ou privés. 


\title{
Production of green juice with an intensive thermo-mechanical fractionation process. Part II: Effect of processing conditions on the liquid fraction properties
}

\author{
S. Kerfai ${ }^{a, b, c, *}$, A. Fernández ${ }^{a, b, c}$, S. Mathé ${ }^{a, b, c}$, S. Alfenore ${ }^{a, b, c}$, P. Arlabosse $e^{d, e}$ \\ a Université de Toulouse, INSA, UPS, INP, LISBP, 135 Avenue de Rangueil, F-31077 Toulouse, France \\ b INRA, UMR792 Ingénierie des Systèmes Biologiques et des Procédés, F-31400 Toulouse, France \\ c CNRS, UMR5504, F-31400 Toulouse, France \\ d Université de Toulouse, Mines Albi, CNRS, Campus Jarlard, F-81013 Albi, France \\ ${ }^{\mathrm{e}}$ Ecole des Mines Albi, Centre RAPSODEE, Campus Jarlard, F-81013 Albi, France
}

Keywords:

Green juice

Valorisation

TAMD process

Physico-chemical characterisation

Rubisco

HPLC SEC analysis

\begin{abstract}
A B S T R A C T
The thermally assisted mechanical dewatering (TAMD) process proved to be efficient to dewater various biomasses. The main idea of this process is to supply heat by conduction through the press walls during the wet fractionation. Applied to spinach leaves, this process led to energy saving but also to a larger amount of green juice. In order to optimize the TAMD process and to evaluate the valorisation potential of the liquid fraction produced, the physico-chemical characteristics of the green juice were investigated.

In addition to conventional characterisation methods, an analysis method specific to Rubisco protein (ribulose-1,5-bisphosphate carboxylase/oxygenase) has been developed in the present work. The method enables detection and quantification of Rubisco in green juice samples by using size exclusion chromatographic principles (HPLC SEC).

Global methods showed that cut degree of the biomass leaves has an effect on the liquid fraction produced. Indeed, nitrogen content, green and white proteins contents are higher when leaves are finely cut.

The investigation of temperature processing effect on juice characteristics by applying the different characterisation methods leads to:

- At high temperature $\left(90^{\circ} \mathrm{C}\right)$, low nitrogen and fractionated proteins contents in juice, which means that an enriched press cake is produced.

- At medium temperature $\left(50^{\circ} \mathrm{C}\right)$, higher nitrogen content in juice, which means that a polypeptides-rich liquid I produced.

- At low temperature $\left(30^{\circ} \mathrm{C}\right)$, HPLC SEC method developed revealed that TAMD process produced a green
\end{abstract} juice containing biomolecules of high added value such as Rubisco protein.

\section{Introduction}

According to the principle of sustainability, a modern society should preserve non-renewable energy sources and replace them with renewable energy. Biorefinery is widely defined as "the sustainable processing of renewable biomass into a variety of valueadded products (chemicals, materials, food and feed) and energy (biofuels, power and heat)" [1]. Biorefineries usually process agri-

\footnotetext{
* Corresponding author at: Université de Toulouse, INSA, UPS, INP, LISBP, 135 Avenue de Rangueil, F-31077 Toulouse, France. Tel.: +33 5615597 91; fax: +33561559760.

E-mail address: syrine.kerfai@insa-toulouse.fr (S. Kerfai).
}

culture or forest biomass such as sugar and starch crops, vegetable oils, grasses, whey, lignocellulosic materials and different organic wastes such as municipal solid wastes and residues from the food production chain, to produce energy and a wide variety of chemical precursors and bio-based materials.

Renewable resources derived from biomass plants, also referred to as biofuel, bioenergy, or bioresources are sufficiently similar to fossil fuel to provide substitution. Especially, renewable grass resources derived from extensive land cultivation or other natural resources such as alfalfa, are excellent biorefinery raw materials [2]. Green biorefineries are dedicated to the processing of these green grasses.

The first processing step of the green biorefinery is the wet fractionation. This process separates the plant material under pressure 
effect into two broad components: (1) water-insoluble components (press cake usually used for animal feed) and (2) carbohydrateand protein-rich water-soluble fraction [3]. The liquid fraction is a nutrient-rich green juice containing proteins, free amino acids, organic acids, dyes, enzymes, hormones, further organic substances, and minerals. This is the reason why it constitutes a raw material for several high value products such as lactic acid and corresponding derivatives, amino acids, ethanol, and proteins [4].

The thermally assisted mechanical dewatering (TAMD) process, designed since several years now in the RAPSODEE Research Center, proved to be efficient to dewater various biomasses under a variety of processing conditions ranging from 21 to $90^{\circ} \mathrm{C}$ and from 300 to $3000 \mathrm{kPa}$ [5]. The main idea of this process is to supply heat by conduction through the press walls during the wet fractionation. It has been illustrated that, when applied to alfalfa, the TAMD process can remove up to $69 \%$ of the inherent liquid fraction with a onestage thermally assisted compression [6] and up to $83 \%$ with a twostage thermally assisted compression [7]. As the extraction yield of conventional process with prior pulping amounts to 55\%, the TAMD process is able to produce a much larger amount of green juice. Besides, the use of the TAMD process before the drying of the dewatered alfalfa cake leads to an energy saving of at least $30 \%$ on the overall separation chain. Indeed, the energy consumption of the TAMD process is less than $150 \mathrm{kWh} / \mathrm{m}^{3}$ [8].

In addition to the energy consumption reduction, recovering high value co-products from the liquid fraction is a real challenge for biorefineries industries to increase the sustainability and the profitability [3]. The relative abundance of proteins in leaf material and the basic need for protein in the human diet are the main reasons for scientists concern to focus on proteins recovery from vegetable biomass. From 1970s on, several developments have been directed toward production of human food grade Leaf Protein Concentrate (LPC) from green juice [9-12]. These last years, several vegetable biomasses revealed their intrinsic value and potentialities as biorefineries feedstocks. The wet fractionation process of alfalfa biomass for example has been the subject of many researches [13-15]. A valorisation process by thermal coagulation and centrifugation was used to recover some compounds, especially proteins an peptides. The final product was a $(92 \%(\mathrm{w} / \mathrm{w})$ moisture) powder containing $82 \%(\mathrm{w} / \mathrm{w})$ protein and was exclusively used as animal feed [16]. d'Alvise [17] and Kapel et al. [18] used enzymatic hydrolysis to produce proteins from an industrial alfalfa soluble protein concentrate.

The TAMD process is likely to extract green juice in larger quantities than conventional fractionation processes. Furthermore, the liquid fraction composition will probably vary depending on the operating conditions of the TAMD process. Indeed, some of the green juice components have a low resistance to thermal treatments. In addition, the mechanisms of water transportation in plant cells are related to temperature [6], so the green juice composition can be used for process control. Besides, the valorisation potential of the liquid fraction produced by biomass dehydration depends on its biomolecules content and their characterisation is necessary to define the most adapted valorisation process. Therefore, global and specific characterisation methods development allows not only a specific valorisation but also a control of the dewatering process.

To date, in the wet fractionation plant, the green juice has been only characterised by its protein content determined by its nitrogenous matter according to Kjeldahl analysis (Procedure V18-100; AFNOR, 1985) [19]. Starke et al. [2] developed a qualitative and quantitative analysis of carbohydrates in green juices by gas chromatography/mass spectrometry. More specific analysis of the green juice was performed by proteomics. Studies of genome products and establishment of proteome maps of alfalfa juice were investigated by Incamps et al. [19]. However no specific quantitative method is available in the literature.
For green biomass, the chlorophyll, xantophyll, carotene and other fatty materials like hydrophobic proteins of leaves (commonly called green), are contained in small bodies in cells of leaf, called chloroplasts. These chloroplasts are suspended in the liquid cell which contains a hydrophilic protein mixture. The hydrophilic proteins have been designed as white proteins although a part of it comes from broken chloroplasts [20]. Purification and technological evaluation of the main hydrophilic protein of leaves Rubisco (ribulose-1,5-bisphosphate carboxylase/oxygenase, EC 4.1.1.39) has been the subject of several studies. Rubisco is one of the largest proteins in nature. It is a globular protein and in higher plants having molecular weight (MW) close to $560 \mathrm{kDa}$. The general structure of Rubisco is L8S8-eight large subunits with MWs around $56 \mathrm{kDa}$ and eight small subunits with MWs close to $14 \mathrm{kDa}$. Four dimers of the large subunit constitute a core of eight large subunits with a 4-fold axis of symmetry and a barrel-like general shape $[21,22]$. Owing to its natural abundance in chloroplasts and its physico-chemical properties, this protein could be obtained with a good yield and a high level of purity [22]. Separation of the white hydrophilic protein fraction from the cell wall components opens opportunities of products marketing for ruminant and nonruminant organisms, furthermore, recovering of Rubisco fraction offers potentialities to enzymatic activity application such as its immobilisation for a carbon dioxide fixation bioprocess [23].

The aim of this work was to characterise the composition of the green juices produced by TAMD process in order to evaluate their potential of valorisation but also to evaluate their capacity for process control. Physico-chemical properties of green juices produced by the TAMD process applied to spinach leaves were investigated. The choice of Spinach leaves as green vegetable biomass, for this study, is due to the availability of partially purified Rubisco extracted from this plant. Partially purified Rubisco of Spinach, commercialised in powder form, was thus considered as a reference for the development of qualitative and quantitative characterisation methods. Global characterisation, such as fractionation of juice proteins according to their hydrophobicity and total nitrogen content were also carried out. A method of detection and quantification of Rubisco in the wet fraction by HPLC size exclusion chromatography was developed to highlight the effects of operating conditions on this protein and to optimize the TAMD process for their production. Finally sodium dodecyl sulphate polyacrylamide gel electrophoresis (SDS-PAGE) was carried out to check the two Rubisco subunits presence.

\section{Material and methods}

\subsection{Vegetable material}

Green juice samples were produced with the TAMD process, according to the protocol described by Arlabosse et al. [6], from spinach leaves cut at different degrees and produced under constant temperature from 30 to $90^{\circ} \mathrm{C}$. Three cutting levels were considered: none (whole leaves), coarse (leaves chopped into pieces of $3 \mathrm{~cm} \times 3 \mathrm{~cm}$ ) and fine (leaves chopped into $0.5 \mathrm{~cm}$ broad bands). The samples were immediately frozen $\left(-20^{\circ} \mathrm{C}\right)$ after production and defrozen at $6^{\circ} \mathrm{C}$ before characterisation. Fig. $1 \mathrm{sum}-$ marises the steps of biomass fractionation and physico-chemical characterization that have been followed in this work.

\subsection{Biomolecules}

Molecular weight marker proteins used for HPLC size exclusion chromatography (HPLC SEC) were from Amersham-Pharmacia. These proteins and their molecular weights (MWs) are given in Table 1. 


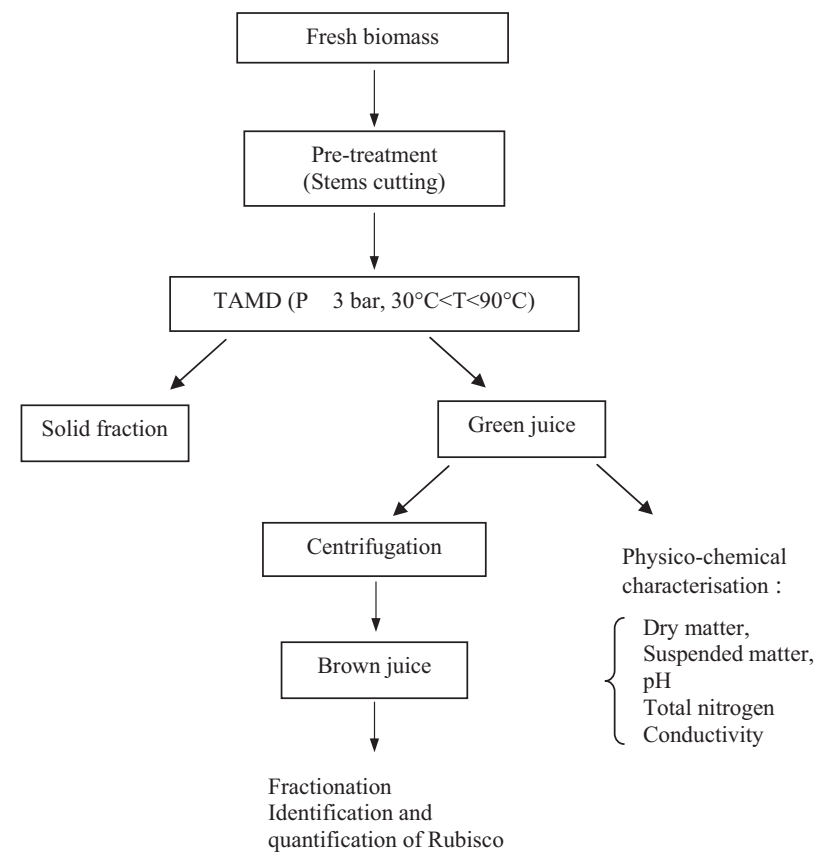

Fig. 1. Global layout of spinach fractionation and physico-chemical characterisation steps.

Molecular weight markers from Bio-Rad, mentioned in Table 2, were used for sodium dodecyl sulphate polyacrylamide gel electrophoresis analysis.

Commercial Rubisco from Spinach (Sigma Aldrich, France) were used in this work as a reference for detection and quantification of Rubisco in the juice samples. This protein is commercialised as a partially purified powder, soluble in $1 \mathrm{M}$ Tris $\mathrm{HCl}, \mathrm{pH} 7.8$.

To estimate the purity of the commercial Rubisco, dialysis treatment was carried out to remove all compounds of molecular weight lower than $300 \mathrm{kDa}$. Rubisco solution was dialysed for $30 \mathrm{~h}$ at $4{ }^{\circ} \mathrm{C}$ with a dialysis membrane from Biovalley (France) of $300 \mathrm{kDa}$ molecular weight cutt-off. The purity of Rubisco solution was estimated as being $70 \%$.

\subsection{Conventional methods}

The $\mathrm{pH}$ and the electrical conductivity were measured prior any juice sample characterisation. Dry solids content and suspended matter were then determined for each sample according to the AFNOR standard protocols 90-105 [24]. The juice was dried at $105^{\circ} \mathrm{C}$ for $24 \mathrm{~h}$. Suspended matter was eliminated by centrifugation at $5000 \times \mathrm{g}$ for $10 \mathrm{~min}$ to remove cell debris.

\subsubsection{Nitrogen content}

Total nitrogen content was determined in crude juice samples by the Kjeldhal procedure [19] with Büchi K-425 and K-350 (Büchi Rungis, France) equipments. Raw juice samples were diluted in deionised water. As commonly seen for biomass proteins $[18,25]$, a factor of 6.25 was used to convert nitrogen into proteins.

\subsubsection{Proteins fractionation}

Alfalfa proteins are divided into two main groups which are hydrophobic and hydrophilic proteins. The fraction of hydrophobic proteins is usually called "green" fraction because of the association of its proteins to coloured compounds such as chlorophyll and xantophyll, whereas hydrophilic proteins are called "white" proteins. At the laboratory scale, separation of hydrophobic from hydrophilic proteins often includes a precipitation step. Bahr et al. [26] proved that saturation close to $30 \%$ of ammonium sulphate allows green hydrophobic proteins precipitation while white hydrophilic proteins remain in solution. Precipitation of hydrophilic proteins fraction was demonstrated at $55 \%$ of ammonium sulphate by Hall et al. [27]. Rubisco generally precipitates at $50 \%$ saturation of $\left(\mathrm{NH}_{4}\right)_{2} \mathrm{SO}_{4}$ though some small differences have been noticed between Rubiscos of different botanical origins [26]. For example, Rubisco from spinach, the only Rubisco commercialised as a partially purified powder by Sigma Aldrich, is prepared by ammonium sulphate fractionation followed by dialysis prior to lyophilisation.

Suspended matter free juice was fractionated by ammonium sulphate to separate "green" hydrophobic and "white" hydrophilic proteins. Ammonium sulphate was added to the juice sample to obtain a $27 \%$ saturated solution. The precipitated hydrophobic proteins were separated by centrifugation $(15 \mathrm{~min}$ at $5000 \times \mathrm{g})$. The pellet of hydrophobic proteins was washed with deionised water, dried at $105^{\circ} \mathrm{C}$ and weighed. The supernatant was saturated to $55 \%$ with ammonium sulphate to precipitate hydrophilic proteins. The separation of white proteins was obtained by centrifugation for $15 \mathrm{~min}$ at $5000 \times \mathrm{g}$ and the pellet of hydrophilic proteins was washed, dried at $105^{\circ} \mathrm{C}$ and weighed.

\subsubsection{SDS-PAGE electrophoresis}

As Rusbico is a multimeric protein, SDS-PAGE enables to visualise the large and small subunits. Comparison between bands of commercial Rubisco and bands of different juice samples produced with TAMD process will highlight differences in conformation, if any.

SDS-PAGE was carried out using a 15\% resolving gel following the procedure described by Laemmli [28]. Acrylamide, bisacrylamide, SDS, TEMED, ammonium persulfate and $\beta$ mercaptoethanol were purchased from Sigma Aldrich, France.

Electrophoresis procedure was performed for juice samples produced from spinach leaves finely cut, at $30,50,70$ and $90^{\circ} \mathrm{C}$, using the Mini Protean II Cell system (Bio-Rad, France). Gels were stained using Coomassie brilliant blue R-250.

Table 1

Molecular weight proteins marker used for HPLC SEC column calibration.

\begin{tabular}{lllllllll}
\hline Protein & Aprotinin & Ribonuclease A & Ovalbumin & Conalbumin & Aldolase & Catalase & Ferritin & Thyroglobulin \\
\hline MW $(\mathrm{kDa})$ & 6.5 & 13.7 & 43 & 72 & 128 & 232 & 440 & 669 \\
\hline
\end{tabular}

Table 2

Molecular weight markers used for SDS-PAGE analysis.

\begin{tabular}{|c|c|c|c|c|c|c|}
\hline Protein & Phosphorylase b & Bovine serum albumin & Ovalbumin & Carbonic anhydrase & Soybean trypsin inhibitor & Lysozyme \\
\hline MW (kDa) & 97 & 66.2 & 45 & 31 & 21 & 14.4 \\
\hline
\end{tabular}




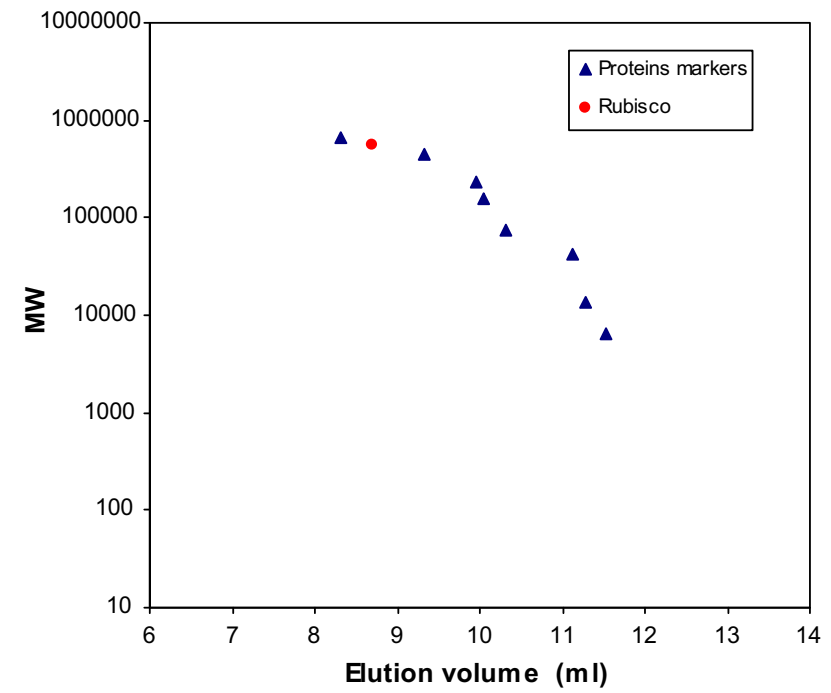

Fig. 2. Calibration curve of HPLC SEC column (Protein KW804 column, Shodex) carried out with proteins markers: Aprotinin, Ribonuclease A, Ovalbumin, Conalbumin, Aldolase, Catalase, Ferritin, Thyroglobulin. Rubisco molecular weight as a function of its elution volume is shown.

\subsection{Rubisco analysis method}

Specific method for Rubisco detection and quantification was developed. Among white hydrophilic proteins, Rubisco is the most abundant. Knowledge of Rubisco structure and its physicochemical properties especially its molecular weight (MW) leads to conclude that Rubisco represents most probably the highest molecular weight protein among leaves white proteins. Therefore, size exclusion chromatography constitutes an adequate method to identify and quantify Rubisco in juice samples.

A silica-based $(8 \times 300)$ Protein KW804 column (Shodex, Tokyo, Japan) was selected. The column was firstly calibrated by analysing proteins of different molecular weight (see Table 1 ), to establish the correlation between the elution volume and the molecular weight.

Äkta purifier system (Amersham Biosciences, Uppsala, Sweden) was used. Analyses were carried out with an injection loop of $0.1 \mathrm{ml}$, with phosphate buffer solution $4 \mathrm{mM}$ pH 6.8 and $25 \mathrm{mM} \mathrm{Na}_{2} \mathrm{SO}_{4}$ eluent at a flow rate of $1 \mathrm{ml} / \mathrm{min}$. The analysis was coupled with a measurement of the absorbance at $280 \mathrm{~nm}$ by means of a UV detector. Absorbance 254 and $210 \mathrm{~nm}$ were also carried out but were less specific to protein detection, especially Rubisco.

A column calibration curve consists on the relationship between the protein $\mathrm{MW}$ and the liquid volume used for the protein moving in the column until its exclusion. This volume is called elution volume and is as high as the MW of the protein is low. Fig. 2 shows the calibration curve of the HPLC SEC column carried out with the pure proteins mentioned before. It can be seen that the separation range of the HPLC SEC column is included between 8.3 and $11.7 \mathrm{ml}$. According to this calibrating curve, a molecular weight protein of $560 \mathrm{kDa}$ is expected to be eluted from the column at $8.8 \mathrm{ml}$.

Commercial Rubisco from spinach was then analysed with this HPLC SEC protocol. Absorbance at $280 \mathrm{~nm}$ as a function of the elution volume, called chromatogram, is plotted in Fig. 3 for Rubisco solution at $1 \mathrm{~g} \mathrm{~L}^{-1}$.

As expected, Rubisco solution was not pure since the chromatogram revealed many absorbance peaks. The first absorbance peak F1, observed at an elution volume of $8.74 \mathrm{ml}$, corresponds to a molecular weight close to $570 \mathrm{kDa}$. Compounds eluted at higher volumes from 10 to $12 \mathrm{ml}$ correspond to molecular weights ranging from 60 to $6 \mathrm{kDa}$. They constitute the fraction F2.

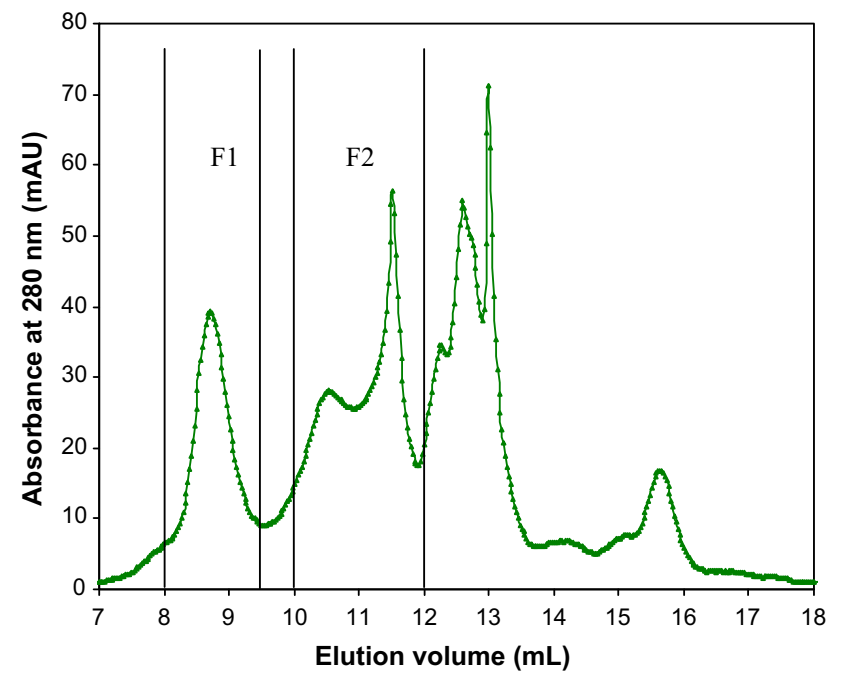

Fig. 3. HPLC SEC chromatogram obtained for spinach Rubisco solution at $1 \mathrm{~g} \mathrm{~L}^{-1}$. Sample volume is $0.1 \mathrm{ml}$, PBS eluent with a flow rate of $1 \mathrm{ml} / \mathrm{min}$. F1 is the fraction having a MW close to $570 \mathrm{kDa}$ and F2 is the fraction of MW between 60 and $6 \mathrm{kDa}$.

Compounds eluted at volumes higher than $12 \mathrm{ml}$ correspond to molecular weights compounds lower than $6 \mathrm{kDa}$. Their MWs cannot be determined exactly since they are out of the separation range of the column. However, the scale of the chromatogram was extended until the baseline returns to zero.

F1 and F2 fractions were collected separately from HPLC SEC column and analysed by SDS-PAGE. Fig. 4 shows the gel revealed with Coomassie blue after migration of Rubisco solution (in lane 3), F1 (in lane 4), F2 (in lane 5), lysozyme (in lane 2) and BSA (in lane 1).

When compared to protein markers, Rubisco solution presented one first band corresponding to a molecular weight of $58 \mathrm{kDa}$ and a second band that appeared at the same level of lysozyme band $(14 \mathrm{kDa})$. Intermediate MW bands were also detected in Rubisco lane migration. Migration of F1 on the SDS-PAGE showed only two bands at the same level of the two bands detected with Rubisco solution (of 58 and $14 \mathrm{kDa}$ ), while F2 showed the intermediate MW bands.

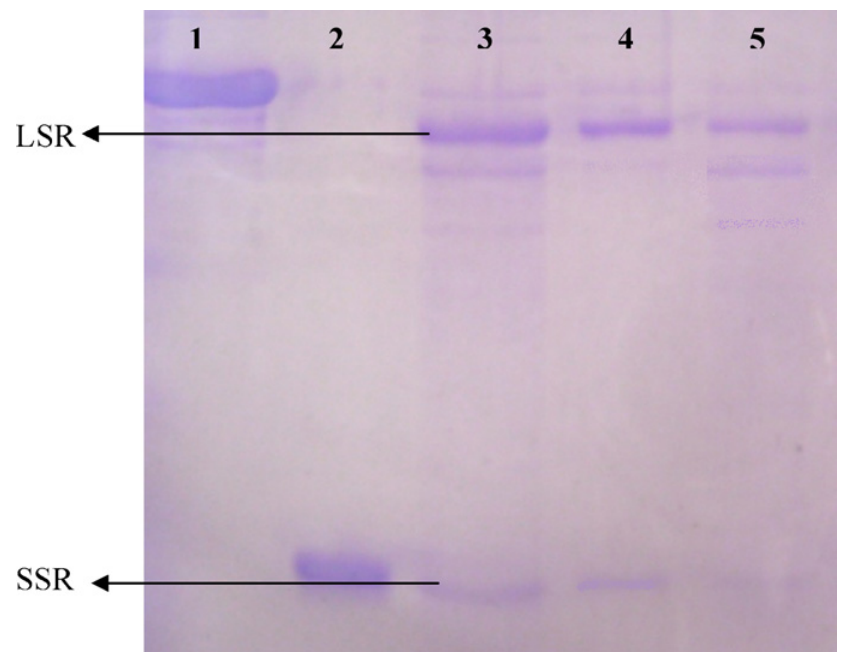

Fig. 4. Rubisco fractions analysis on SDS-PAGE $15 \%$. From left to right: lane $1 \mathrm{BSA}$, lane 2 lysozyme migration, lane 3 commercialised spinach Rubisco, lane $4 \mathrm{~F} 1$, lane 5 F2. LSR: large subunit of Rubisco; SSR: small subunit of Rubisco. 


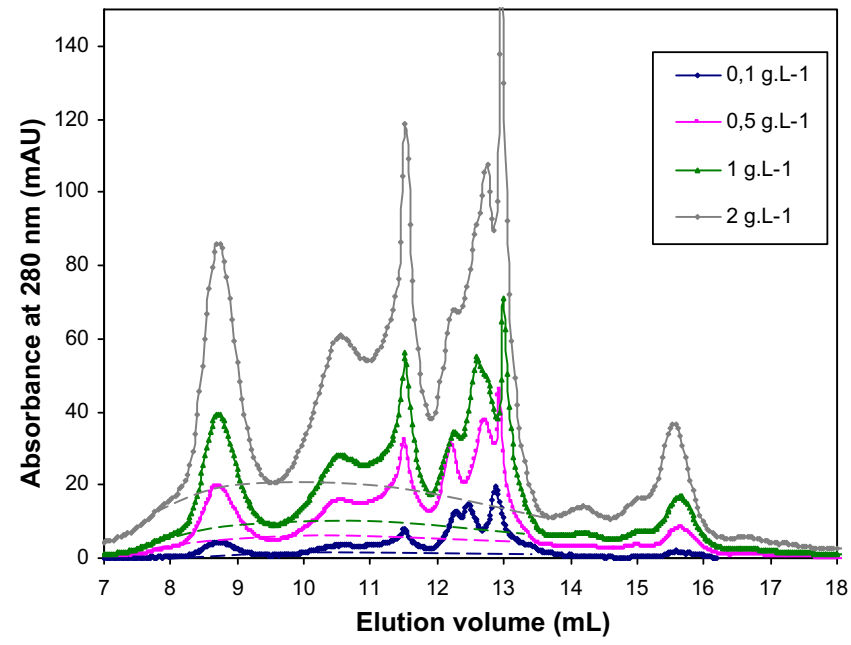

Fig. 5. HPLC SEC chromatograms obtained for spinach Rubisco solutions. Sample volume is $0.1 \mathrm{ml}$, concentrations in Rubisco vary from 0.1 to $2 \mathrm{~g} \mathrm{~L}^{-1}$, PBS eluent with a flow rate of $1 \mathrm{ml} / \mathrm{min}$.

This seems coherent with HPLC SEC results. The first peak F1 detected in HPLC SEC analysis (eluted at $8.74 \mathrm{ml}$ ) corresponds probably to the purified Rubisco whereas F2 is concerned with compounds of lower MWs, between 58 and $14 \mathrm{kDa}$.

The HPLC SEC method developed seems able to detect Rubico protein in aqueous solution. The peak at an elution volume of $8.74( \pm 5 \%)$ was then considered as an indicator of the presence of Rubisco in green juice samples (Fig. 2).

In order to quantify Rubisco content in juice samples, a calibration curve has been established by injection of Rubisco solutions, prepared by dissolution of the partially purified powder in $1 \mathrm{M}$ Tris $\mathrm{HCl} \mathrm{pH} 7.8$ buffer, at different concentrations. The chromatograms obtained are shown in Fig. 5.

Rubisco peak areas were calculated for each concentration with a baseline adjustment as shown in Fig. 5, since the amount of impurities increases when the concentration of the Rubisco solution increases. Fig. 6 presents the calibration curves performed for Rubisco solutions with different concentrations ranging from 0.1 to $2 \mathrm{~g} \mathrm{~L}^{-1}$.

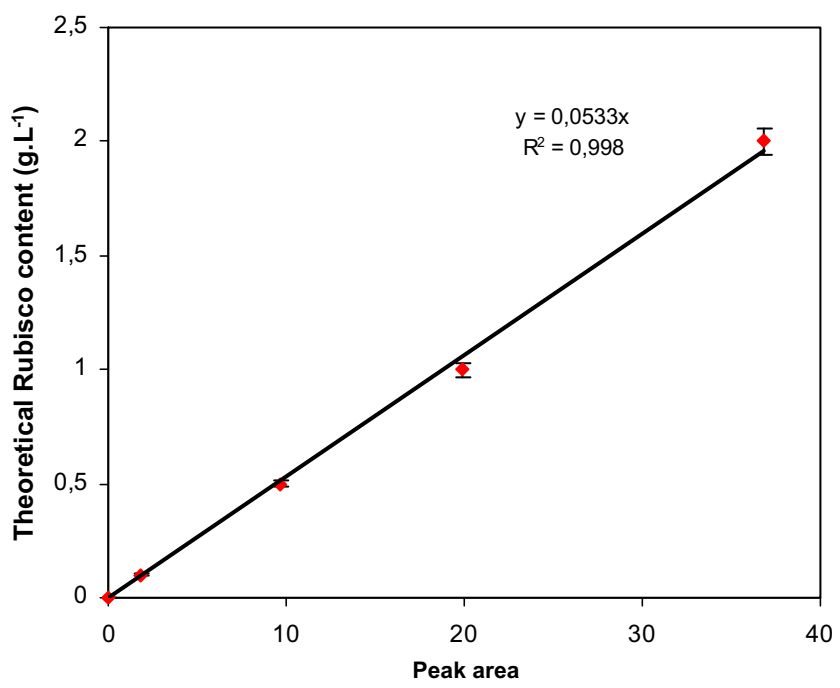

Fig. 6. Calibration curve: Rubisco peak area versus theoretical Rubisco content (from 0.1 to 2 g.L $\left.\mathrm{L}^{-1}\right)$.
Table 3

Studied operating conditions of the TAMD process for green juice production.

\begin{tabular}{llllllll}
\hline $\begin{array}{c}\text { Wall temperature of } \\
\text { the press }\end{array}$ & $50{ }^{\circ} \mathrm{C}$ & & $30{ }^{\circ} \mathrm{C}$ & $50{ }^{\circ} \mathrm{C}$ & $70^{\circ} \mathrm{C}$ & $90^{\circ} \mathrm{C}$ \\
\hline Cutting level & None & Coarse & Fine & Fine & Fine & Fine & Fine \\
\hline
\end{tabular}

Table 4

Characteristics of spinach juices produced from different degrees of leaf cutting with the TAMD process at $50^{\circ} \mathrm{C}$.

\begin{tabular}{lccc}
\hline Temperature & $50{ }^{\circ} \mathrm{C}$ & & \\
\cline { 2 - 4 } Cutting level & None & Coarse & Fine \\
\hline $\mathrm{pH}$ & 6.7 & 6.5 & 6.6 \\
Conductivity $\left(\mathrm{mS} \mathrm{cm}^{-1}\right)$ & 18.9 & 19.0 & 20.7 \\
Dry solid $\left(\mathrm{g} \mathrm{L}^{-1}\right)$ & 37.2 & 38.6 & 32.1 \\
Suspended matter $\left(\mathrm{g} \mathrm{L}^{-1}\right)$ & 2.33 & 1.45 & 1.3 \\
Total nitrogen $\left(\mathrm{m} \mathrm{L} \mathrm{L}^{-1}\right)$ & 1960 & 2450 & 2730 \\
Total nitrogen $\left(\mathrm{g} \mathrm{proteins} \mathrm{L}^{-1}\right)$ & 12.25 & 13.56 & 15.31 \\
Green proteins $\left(\mathrm{g} \mathrm{L}^{-1}\right)$ & 4.01 & 3.68 & 3.11 \\
White proteins $\left(\mathrm{g} \mathrm{L}^{-1}\right)$ & 5.41 & 7.28 & 9.6 \\
Total fractionated proteins $\left(\mathrm{g} \mathrm{L}^{-1}\right)$ & 9.44 & 10.96 & 12.71 \\
\hline
\end{tabular}

Rubisco concentration can be determined by the following equation:

$C=53 \times 10^{-3} \times A$

where $A$ is the peak area, $C$ is the Rubisco concentration in $g \mathrm{~L}^{-1}$.

To estimate the accuracy of the measures, Rubisco solutions of well-known concentration were injected and their concentrations were calculated by means of Eq. (1). The error was evaluated to $10 \%$. This relationship was used for green juice to quantify Rubisco. Centrifuged juice samples, produced by the TAMD process, were then injected in the HPLC SEC column and their Rubisco content was determined.

\section{Results and discussion}

These characterisation methods were applied for the spinach juices produced by TAMD process at the different operating conditions summarised in Table 3.

In order to study the influence of the cutting and heat supply on the juice composition, the physico-chemical properties ( $\mathrm{pH}$, conductivity, dry solid, suspended matter and total nitrogen content) of the raw juice were firstly measured. Protein fractionation and HPLC SEC analysis were then carried out for juice samples free of suspended matter.

\subsection{Biomass pre-treatment effect}

As mentioned previously, the effect of physical structures of the biomass on the juice composition was investigated. Wall temperature was fixed at $50^{\circ} \mathrm{C}$ to produce green juice by TAMD process. Three cuttings were considered for spinach leaves: none, coarse and fine. Table 4 summarises the physico-chemical properties of the juices extracted from spinach leaves under these conditions.

For the three cutting levels of the spinach leaves, global physicochemical parameters, such as pH, conductivity, dry matter and suspended matter, were similar for all samples. Cutting level has an influence on both the total nitrogen content, assumed as crude proteins content, and the white proteins content: crude and white proteins contents increased when spinach leaves are more finely cut. On the contrary, the cutting level does not change the green protein content.

This result can probably be explained by the localisation of the two kinds of proteins: white hydrophilic proteins are located in cells organist called stroma which are inside chloroplasts [29]. Thus, 


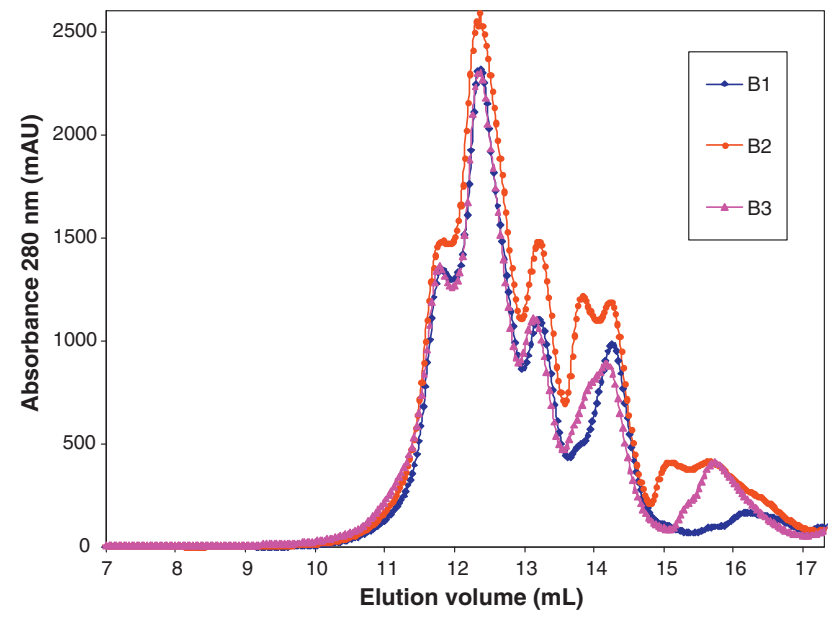

Fig. 7. HPLC SEC chromatograms of juice samples produced at $50^{\circ} \mathrm{C}$ from spinach leaves with three cutting levels: B1: none, B2: coarse and B3: fine.

to extract this kind of proteins, cells must be disrupted as much as possible. Otherwise, green proteins constitute membrane proteins and do not need a mechanical extraction to be expressed from the leaf cells.

\subsubsection{HPLC SEC characterisation}

According to the protocol described in Section 2, suspended matter free juices produced by dehydration of spinach stems cut at different levels, were analysed by HPLC SEC. The chromatograms obtained are plotted in Fig. 7 for samples at the three cutting levels.

No peak appeared for an elution volume around $8.75 \mathrm{ml}$ indicating the absence of Rubisco in the juices produced under these operating conditions: whatever the cutting level, green juice produced at $50^{\circ} \mathrm{C}$ did not contain Rubisco in native form.

\subsection{Temperature effect}

Juice samples produced at different temperatures with spinach leaves finely cut were then characterised. Table 5 summarises global physico-chemical properties of green juice extracted with a wall temperature set to $30,50,70$ and $90^{\circ} \mathrm{C}$ as is described by Arlabosse et al. [6].

For all juice samples, global physico-chemical properties such as $\mathrm{pH}$, suspended matter and conductivity were similar. Process parameters studied are of low influence on these global properties which does not seem appropriate to control the process.

Green hydrophobic proteins content was lower than white hydrophilic proteins content whatever the temperature wall. Green and white proteins in spinach leaves are usually reported to be present on equal proportions [29]. Costes [29] reported that for $1 \mathrm{~g}$ of fresh spinach leaves, there are $18.2 \mathrm{mg}$ proteins: $9 \mathrm{mg}$ are

Table 5

Characteristics of spinach juice samples produced at different wall temperatures.

\begin{tabular}{|c|c|c|c|c|}
\hline \multirow{2}{*}{$\begin{array}{l}\text { Cutting level } \\
\text { Temperature }\end{array}$} & \multicolumn{4}{|l|}{ Fine } \\
\hline & $30^{\circ} \mathrm{C}$ & $50^{\circ} \mathrm{C}$ & $70^{\circ} \mathrm{C}$ & $90^{\circ} \mathrm{C}$ \\
\hline $\mathrm{pH}$ & 6.6 & 6.6 & 6.9 & 6.6 \\
\hline Conductivity $\left(\mathrm{mS} \mathrm{cm}^{-1}\right)$ & 19.6 & 20.7 & 20.2 & 18.7 \\
\hline Dry solid $\left(\mathrm{g} \mathrm{L}^{-1}\right)$ & 20.5 & 32.1 & 31.0 & 33.4 \\
\hline Suspended matter $\left(\mathrm{g} \mathrm{L}^{-1}\right)$ & 2.2 & 1.3 & 1 & 2.4 \\
\hline Total nitrogen ( $\left.\mathrm{mg} \mathrm{L}^{-1}\right)$ & 1890 & 2730 & 2380 & 1750 \\
\hline Total nitrogen ( $g$ proteins $\mathrm{L}^{-1}$ ) & 11.81 & 15.31 & 12.87 & 10.93 \\
\hline Green proteins $\left(\mathrm{g} \mathrm{L}^{-1}\right)$ & 1.96 & 3.11 & 3.52 & 2.02 \\
\hline White proteins $\left(\mathrm{g} \mathrm{L}^{-1}\right)$ & 7.56 & 9.6 & 7.36 & 6.24 \\
\hline Total fractionated proteins $\left(\mathrm{g} \mathrm{L}^{-1}\right)$ & 9.52 & 12.71 & 11.88 & 8.26 \\
\hline
\end{tabular}

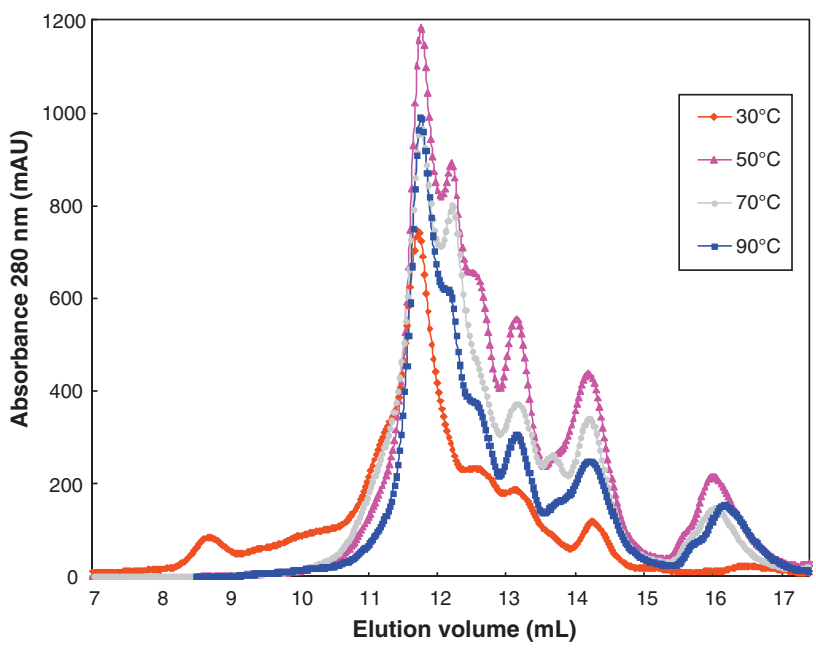

Fig. 8. HPLC SEC chromatograms obtained for spinach juice samples produced by the TAMD at different wall temperatures $\left(30,50,70\right.$ and $\left.90^{\circ} \mathrm{C}\right)$.

hydrophilic proteins which result from break-up of chloroplasts and from cytoplasm. The other $9.2 \mathrm{mg}$ are hydrophobic proteins, mainly membranes proteins, which are generally separated from hydrophilic ones by sedimentation.

In this work, fractionation of proteins was carried out on juices free of solids. Therefore, the removal of the suspended matter, which contains a large proportion of hydrophobic proteins, could explain the present results. This could also explain the difference on the mass balance between fractionated proteins and crude proteins, since several membranes proteins are removed with suspended matter (cells debris).

As expected, the operating temperature of the TAMD process has an influence on the crude protein content. Spinach juice produced at $50^{\circ} \mathrm{C}$ presents the maximal nitrogen, green protein and white protein contents. Gastineau and Mathan [30] reported that green proteins, usually considered as chloroplastic proteins, precipitate between 55 and $65^{\circ} \mathrm{C}$ and that white proteins, considered as cytoplasmic proteins, precipitate at $85^{\circ} \mathrm{C}$. Arlabosse et al. [6] noticed that, when juice is produced at $50^{\circ} \mathrm{C}$, the temperature of the bottom of the press cake reaches $50^{\circ} \mathrm{C}$ after $2 \mathrm{~h}$ and half processing, while it reaches $66^{\circ} \mathrm{C}$ after $20 \mathrm{~min}$ when processing at $70^{\circ} \mathrm{C}$. This could explain why protein content is higher in juices produced at 50 than those produced at 70 and $90^{\circ} \mathrm{C}$. In addition, heat could modify structure and conformation of proteins, which modifies their solubility properties and their behaviour [31], or have an influence on the physical mechanisms involved on the juice production having an effect on the bio-molecule content.

\subsubsection{HPLC SEC characterisation}

Chromatograms obtained by HPLC SEC analysis of spinach juice obtained with different wall temperatures are presented in Fig. 8.

The chromatogram of the juice sample produced at $30^{\circ} \mathrm{C}$ showed two absorbance peaks, the first one at $8.75 \mathrm{ml}$, and the second at $11.65 \mathrm{ml}$. The corresponding MWs of these peaks, determined thanks to the calibration curve of the HPLC SEC column (Fig. 2), were respectively, 560 and $6 \mathrm{kDa}$. This juice sample seems to contain Rubisco. Its concentration was estimated from Eq. (1), between 2.5 and $3 \mathrm{~g} / \mathrm{L}$, which represents more than $40 \%$ of white protein content. However, chromatograms of juice samples produced at higher temperatures $\left(50,70\right.$ and $\left.90^{\circ} \mathrm{C}\right)$ showed only the second peak with higher intensity and did not reveal the presence of Rubisco in the samples.

Finally, results obtained from nitrogen characterisation methods showed that physical structure of the biomass has an effect on 


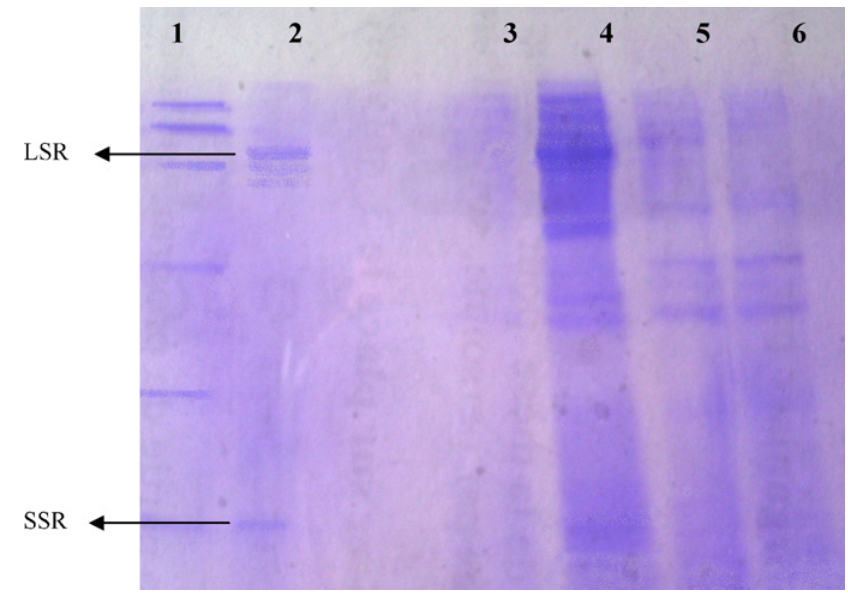

Fig. 9. Spinach juice proteins analysis on SDS-PAGE 15\%. From right to left: lane 1 molecular weight marker, lane 2 spinach Rubisco migration, lane 3 spinach juice produced at $90^{\circ} \mathrm{C}$, lane 4 spinach juice produced at $30^{\circ} \mathrm{C}$, lane 5 spinach juice produced at $50^{\circ} \mathrm{C}$, lane 6 spinach juice produced at $70^{\circ} \mathrm{C}$. LSR: large subunit of Rubisco; SSR: small subunit of Rubisco.

the liquid fraction produced. Indeed, nitrogen content, green and white proteins contents are higher when leaves are finely cut. Nevertheless, at $50^{\circ} \mathrm{C}$, the juice produced by the TAMD process does not contain Rubisco but an important amount of polypeptides and proteins. The developed HPLC SEC method seems to show that TAMD applied at $30^{\circ} \mathrm{C}$ allows Rubisco extraction.

\subsubsection{SDS-PAGE}

To reinforce HPLC SEC results, TAMD juices produced at temperatures from 30 to $90^{\circ} \mathrm{C}$ were loaded on SDS-PAGE. Fig. 9 represents the gel stained by Coomassie Brilliant Blue.

As seen previously, migration of commercial spinach Rubisco on lane 2, revealed two bands making 58 and $14 \mathrm{kDa}$, corresponding respectively to MWs of the large and the small subunits of Rubisco.

Lanes 3, 5 and 6 corresponding to TAMD juices produced with a wall temperature of 90,50 and $70^{\circ} \mathrm{C}$ do not reveal the bands at the same level of the Rubisco subunits. On the contrary, on lane 4 of the TAMD juice produced at $30^{\circ} \mathrm{C}$, two bands corresponding to Rubico subunits were detected in addition to other proteins, peptides and amino acids having low molecular weights. This result is coherent with HPLC SEC results.

\section{Conclusion}

A thermally assisted mechanical dewatering (TAMD) process was applied to spinach leaves. The process involves two simultaneous steps: (1) mechanical dewatering at low pressure and (2) heating. Thus, green crops are separated into a press cake and a green juice.

To control the TAMD process, by understanding physical mechanisms of the biomass dewatering, and to consider the most adapted valorisation way of the liquid fraction, a deep physico-chemical characterisation is necessary. Therefore, in addition to conventional global methods, specific characterisation methods must be developed.

Conventional global methods such as total nitrogen content determination and proteins fractionation were carried out. Results showed that the amount of total nitrogen and fractionated (hydrophobic and hydrophilic) proteins contents increase when crops are finely cut. In addition, they are maximal when the juice is produced at $50^{\circ} \mathrm{C}$ and decrease with increasing temperature. Otherwise, global characterization showed that $\mathrm{pH}$, conductivity, suspended matter and dry matter do not depend on the operating conditions of the dewatering process. Juices produced at temperature higher than $70^{\circ} \mathrm{C}$ showed lower nitrogen content which is normally retained into the medium and allows the production of an enriched cake.

Since proteins are thermally sensitive material (and probably the most interesting valorisable biomolecules), their quality can be modified during juice production. To evaluate the effect of the process on proteins quality and quantity, an analytical method has been developed based on the principles of size exclusion chromatography. The method enables detection and quantification of a specific protein of interest, Rubisco. Results showed that Rubisco was only present in the juice produced at $30^{\circ} \mathrm{C}$, even if total nitrogen content and fractionated proteins are maximal at $50{ }^{\circ} \mathrm{C}$. Therefore, it can be concluded that juice production with an important amount of polypeptides and proteins is possible when dewatering is operated at $50^{\circ} \mathrm{C}$, whereas Rubisco is extracted when operating at $30^{\circ} \mathrm{C}$. The HPLC SEC method developed in this study allowed the control of the dewatering process according to the valorisation path that would be considered.

\section{Acknowledgements}

This research was supported in part French National Research Agency (ANR), in the frame of CP2D program (PRODULUZ project $\mathrm{n}^{\circ}$ ANR-07-CP2D-16-02).

\section{References}

[1] P. Di Donato, G. Anzelmo, G. Tommonaro, B. Nicolaus, A. Poli, Vegetable wastes as suitable biomass feedstock for biorefineries, New Biotechnol. (2009), doi:10.1016/j.nbt.2009.06.575.

[2] I. Starke, A. Holzberger, B. Kamm, E. Kleinpeter, Qualitative and quantitative analysis of carbohydrates in green juices (wild mix grass and alfalfa) from a green biorefinery by gas chromatography/mass spectrometry, Fresenius J. Anal. Chem. 367 (2000) 65-72.

[3] B. Kamm, P. Schonicke, M. Kamm, Biorefining of green biomass - technical and energetic considerations, Clean 37 (2009) 27-30.

[4] S. Kromus, B. Kamm, M. Kamm, P. Fowler, M. Narodoslawsky, in: B. Kamm, M. Kamm, P. Gruber (Eds.), Biorefineries - Biobased Industrial Processes and Products. Status Quo and Future Directions, 1, Wiley-VCH, Weinheim, 2006, pp. 253-294.

[5] A. Mahmoud, A. Fernandez, T. Chitu, P. Arlabosse, Thermally-assisted mechanical dewatering (TAMD) of suspensions of fine particles: analysis of the influence of the operating conditions using the response surface methodology, Chemoof the operating conditions using
sphere 72 (2008) 1765-1773.

[6] P. Arlabosse, M. Blanc, S. Kerfai, A. Fernandez, Production of green juice with an intensive thermo-mechanical fractionation process. Part I: effect of processing conditions on the dewatering kinetics, Chem. Eng. J., submitted for publication, doi:10.1016/j.cej.2011.01.027.

[7] A. Mahmoud, P. Arlabosse, A. Fernandez, Application of a thermally assisted dewatering process to biomass, Biomass Bioenerg. (2010), doi:10.1016/j.biombioe.2010.08.037.

[8] N.C. Grau, Energy balances in biomass dewatering processes, Master's Thesis report, Ecole Des Mines d'Albi-Carmaux, France, 2009, p. 165.

[9] R. Douillard, Propriétés biochimiques et physicochimiques des protéines des feuilles (Biochemical and physico chemical properties of leaves proteins), in: Protéines Végétales, B. Godon (Eds.), Technique et Documentation (Lavoisier), Protéines Végétales, B. Godon

[10] G.O. Kohler, B.E. Knuckles, Edible protein from leaves, Food Technol. 31 (1977) 191.

[11] N.W.Pirie, The present position of research on the use of leaf protein as a human food, Plant Food Hum. Nutr. 1 (1969) 237-246.

[12] L. Telek, H.D. Graham, Leaf Protein Concentrates, AVI Publishing Company, Westport, Connecticut, 1983.

[13] N. Godessart, R. Pares, A. Juarez, Microbial Coagulation of Alfalfa Green Juice, Appl. Environ. Microbiol. 53 (1987) 2206-2211.

[14] W. Koschuh, G. Povoden, V.H. Thang, S. Kromus, K.D. Kulbe, S. Novalin, C. Krotscheck, Production of leaf protein concentrate from ryegrass (Lolium perenne $\times$ multiflorum) and alfalfa (Medicago sativa subsp, sativa). Compariperenne $\times$ multiflorum $)$ and alfalfa (Medicago sativa subsp, sativa). Compari-
son between heat coagulation/centrifugation and ultrafiltration, Desalination son between heat coagul
163 (2004) 253-259.

[15] D. Levesque, J.C. Rambourg, Method for processing the raw juice produced from pressing a protein-leaf rich material such as alfalfa, patent WO 02/058482 (2002).

[16] D. De Fremery, R.E. Miller, R.H. Edwards, B.E. Knuckles, E.M. Bickoff, G. Kohler, Centrifugal separation of white and green protein fractions from alfalfa juice following controlled heating, J. Agric. Food Chem. 28 (1973) 886-889. 
[17] N.P. d'Alvise, C. Lesueur-Lambert, A. Fertin-Bazus, B. Fertin, P. Dhulster, D. Guillochon, Continuous enzymatic solubilisation of alfalfa proteins in an ultrafiltration reactor, Enzyme Microb. Technol. 34 (2004) 380-391.

[18] R. Kapel, A. Chabeau, J. Lesage, G. Riviere, R. Ravallec-Ple, D. Lecouturier, M. Wartelle, D. Guillochon, P. Dhulster, Production, in continuous enzymatic membrane reactor, of an anti-hypertensive hydrolysate from an industrial alfalfa white protein concentrate exhibiting ACE inhibitory and opioid activities, Food Chem. 98 (2006) 120-126.

[19] A. Incamps, F. Hély-Joly, P. Chagvardieff, J.-C. Rambourg, A. Dedieu, E. Linares, E. Quéméneur, Industrial process proteomics: alfalfa protein patterns during wet fractionation processing, Biotechnol. Bioeng. 91 (2005)447-459.

[20] G.O. Kohler, Review of leaf protein concentrate. Production and projected uses, 11th Tech. Alfalfa, ARS 74.60, 1972.

[21] W.E. Barbeau, J.E. Kinsella, Ribulose bisphosphate carboxylase/oxygenase (rubisco) from green leaves-potentials as a food protein, Food Rev. Int. 4 (1988) 93-127.

[22] R. Douillard, O.d. Mathan, Leaf proteins for food use: Potential of RUBISCO, in: B.J. Hudson (Ed.), New and Developing Sources of Food Proteins, Chapman \& Hall, London, 1994, pp. 307-342.

[23] S. Chakrabarti, S. Bhattacharya, S.K. Bhattacharya, Immobilization of Dribulose-1,5-bisphosphate carboxylase/oxygenase a step toward carbon dioxide fixation bioprocess, Wiley Periodicals, Inc., 2002,705-711.
[24] Association Française de Normalisation (AFNOR), Qualité de l'eau, in: Recueil de normes françaises (Collection of French Standard Methods: Water Quality), AFNOR, Paris, France, 1994 (in French).

[25] C. Lusueur-Lambert, N. Prévot-D’Alvise, A.F. Bazus, B. Fertin, P. Dhulster, Development of a pilot process for the production of alfalfa peptide isolate, J. Chem. Technol. Biotechnol. 78 (2003) 518-528.

[26] J.T. Bahr, D.P. Bourque, H.J. Smith, Solubility properties of fraction I proteins of maize, cotton, spinach, and tobacco, J. Agric. Food Chem. 25 (1977) 783-789.

[27] N.P. Hall, D. McCurry, N.E. Tolbert, Storage and maintaining activity of ribulose biphosphate carboxylate/oxygenase, Plant Physiol. 67 (1981) 1220-1223.

[28] U. Laemmli, Cleavage of structural proteins during the assembly of the head of bacteriophage T4, Nature 227 (1970) 680-685

[29] C. Costes, Biochimie des protéines foliaires (Biochemical of leaves proteins), in: Gauthier-Villars Costes (Ed.), Protéines Foliaires et Alimentation, Bordas, Paris, 1981, pp. 1-37 (in French).

[30] I. Gastineau, O.d. Mathan, La préparation industrielle de la protéine verte de luzerne (Industrial processing of green alfalfa protein), in: Gauthier-Villars Costes (Ed.), Protéines Foliaires et Alimentation, Bordas, Paris, 1981, pp. 159-182 (in French).

[31] D.G. Libouga, V. Aguié-Béghin, R. Douillard, Thermal denaturation and gelation of rubisco: effects of $\mathrm{pH}$ and ions international, J. Biol. Macromol. 19 (1996) 271-277. 